https://www.journal-imab-bg.org

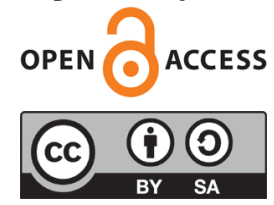

Original article

\title{
FEAR ASSESSMENT WITH THE 'DRAW A PER- SON' TEST OF THE DENTAL TREATMENT IN SPARING ENZYME-BASED EXCAVATION OF CARIES IN CHILDREN BETWEEN 4 AND 6 YEARS OF AGE
}

\author{
Zornitsa Lazarova, Hristina Tankova, Maya Rashkova \\ Department of Pediatric Dentistry, Faculty of dental medicine, Medical Uni- \\ versity - Sofia, Bulgaria.
}

\begin{abstract}
Aim: The aim of the study is to assess fear with the 'Draw a Person' test in sparing enzyme-based excavation with Brix 3000 and conventional excavation when treating carious lesions in primary teeth.

Materials and Methods: The study involves 72 children aged 4-6. The enzyme-based excavation was used at 42 of the children and for the remaining 30 - conventional excavation with a bur.

Each child has to complete the 'Draw a Person' Test: at home, before and after dental treatment in the dental office. The height of each figure is measured in centimeters using a ruler.

Results and Conclusions: Immediately prior to the dental treatment, a double reduction in the size of the figure in both groups could be observed, as compared to the figure drawn at home, which refers to an increase in the fear level. After the end of the treatment, in both groups, an increase could be observed as to the height of the figure drawn, and there is the impression that the height of the figures, drawn by children, where the carious lesions were excavated with Brix 3000 are closer to the figures drawn at home, compared to children treated using the conventional method.
\end{abstract}

Keywords: Fear, 'Draw a Person' Test, EnzymeBased Excavation, Brix 3000,

\section{INTRODUCTION}

The fear of dental treatment could be defined as unusual anxiety brought about by visiting a dental doctor for prophylaxis or treatment or unjustified intimidation from dental procedures. It could bear physiological, cognitive and behavioral implications [1]. Different factors could provoke negative attitudes in children. The dental instruments are one example - children are not familiar with them, as well as treatment methods, pain during treatment, etc. The negative experience of children in their early childhood could lead to an increase in dental anxiety and fear of treatment $[2,3]$.

The fear of dental treatment could continue in adult- hood and could have implications such as avoiding treatment and worsening of oral hygiene as well as the quality of life [4]. Behavioral assessment in children before dental treatment is an important part of the initial examination of the child. A number of tests have been developed to assess and determine the level of dental anxiety in children [5].

Experience shows that a child, which demonstrates fear of dental treatment and is not cooperative during procedures, could circumvent the success of the treatment and cause its impossible conduct $[5,6]$.

Recently, the minimally invasive treatment has been widely used as an alternative to conventional treatment [7]. Atraumatic restorative treatment (ART) becomes popular with little children in the context of minimally invasive treatment. Nowadays, for that purpose, there is a combination of chemical and enzyme-based means with manual excavators, which is considered a suitable atraumatic treatment in the course of treatment of children.

Brix 3000 is a material for sparing enzyme excavation. Its main component is papain, which is bio-capsuled using the EBE Technology (Encapsulating Buffer Emulsion). Brix 3000 operates selectively with its active component softening and removing the irreversibly denaturalized collagen without pain while reserving the partially decomposed collagen in the dentine, which could be restored and remineralized. Upon contact of the gel with the healthy dentine, it loses its enzyme properties due to the presence of antiprotease-1-antitrypsin, which deactivates its enzyme quality.

\section{Aim}

Fear assessment using the 'Draw-a-person' test in sparing enzyme and conventional excavation of carious lesions in primary teeth.

\section{MATERIAL}

72 children were included in the research, aged between 4-6. Sparing enzyme excavation was used on 42 of them with Brix 3000, and the remaining 30 were included in a control group using a conventional excavation with a bur. In accordance with the Frankl scale, children have a 
strong or weak negative attitude towards dental treatment.

Methodology for Assessing Fear of Dental Treatment using the Projective Test 'Draw-a-Person'

The projective test 'Draw-a-Person' assesses fear which children experience in a given situation. Each child is assigned with a task to draw a person at a specific interval of time - at home, before treatment and after the end of the treatment. Children are not made wary of the upcoming treatment. The first figure, drawn at home, is considered to be basic under the assumption that in a situation where they are not aware of the upcoming treatment, they have no reason to experience fear. It has been scientifically proven that the size of the height of the figures correlates with fearing. Figures are measured in centimeters, with the height between the two most remote points taken into account. [8].

For the enzyme-based and the conventional excavation, equally deep dentine carious lesions at stage D3b were selected (as per Peneva).

For the statistical processing of the results, the statistical software program SPSS was used (version 19, SPSS). The level of significance was set at a $95 \%$ interval of reliability $(\mathrm{p}<0,05)$.

\section{RESULTS}

Table 1 shows the average size of the figures drawn by children at home, immediately before and after the dental treatment of the selected carious lesion, excavated with Brix 3000.

Table 1. Comparative Fear Analysis at home, before and after Treatment of the Examined Children, excavated with Brix 3000.

\begin{tabular}{|l|c|c|c|}
\hline \multirow{2}{*}{ Figure Height } & \multicolumn{2}{|c|}{ Total Patients } & Paired T-test \\
\cline { 2 - 3 } & $\mathrm{N}$ & Mean $\pm \mathrm{SD}$ & $\mathrm{t}_{1,2}=18.705 \mathrm{p}_{1,2}<0.05$ \\
\cline { 1 - 2 } At Home $^{1}$ & 42 & $21.12 \pm 4.10$ & $\mathrm{t}_{1,3}=13.551 \mathrm{p}_{1,3}<0.05$ \\
\cline { 1 - 2 } Before Treatment $^{2}$ & 42 & $12.77 \pm 3.44$ & $\mathrm{t}_{2,3}=-14.049 \mathrm{p}_{2,3}<0.05$ \\
\cline { 1 - 2 } After Treatment $^{3}$ & 42 & $18.41 \pm 3.78$ & \\
\hline
\end{tabular}

It could be observed from the table that the average height of the figures drawn at home is $21.12 \mathrm{~cm} . \pm 4.10$. Immediately before the dental treatment, in the dental office, the height of the drawings decreases $-12.77 \mathrm{~cm}$ \pm 3.44 and is significantly increased immediately after the treatment reaching $18.41 \mathrm{~cm} \pm 3.78$. It could be observed that the height of the figures drawn after the treatment is significantly lower compared to the output level, drawn in a state of calmness $(\mathrm{p}<0.05)$.

Table 2 reveals the average values of the height of the figures, drawn at home, before and after the treatment depending on the age of the children, excavated with Brix 3000 .

Table 2. Figure Height $(\mathrm{cm})$ from the Projective Test 'Draw-a-Person' at home - depending on the Age, Excavated with Brix 3000

\begin{tabular}{|c|c|c|c|c|c|c|c|}
\hline \multirow[t]{2}{*}{ Age } & \multicolumn{2}{|c|}{ Figure Height - at home ${ }^{a}$} & \multicolumn{2}{|c|}{$\begin{array}{c}\text { Figure Height - before } \\
\text { Treatment }\end{array}$} & \multicolumn{2}{|c|}{$\begin{array}{c}\text { Figure Height }- \text { after } \\
\text { Treatment }\end{array}$} & \multirow[t]{2}{*}{ Paired T-test } \\
\hline & $\mathrm{N}$ & Mean \pm SD & $\mathrm{N}$ & Mean \pm SD & $\mathrm{N}$ & Mean \pm SD & \\
\hline 4 years old ${ }^{1}$ & 18 & $21.50 \pm 3.52$ & 18 & $14.18 \pm 2.68$ & 18 & $18.58 \pm 3.04$ & $\begin{array}{l}\mathrm{t}_{\mathrm{a}, \mathrm{b}}=10.169 \mathrm{p}_{\mathrm{a}, \mathrm{b}}=0.000 \\
\mathrm{t}_{\mathrm{a}, \mathrm{c}}=8.804 \mathrm{p}_{\mathrm{a}, \mathrm{c}}=0.000 \\
\mathrm{t}_{\mathrm{b}, \mathrm{c}}=-6.688 \mathrm{p}_{\mathrm{b}, \mathrm{c}}=0.000\end{array}$ \\
\hline 5 years old ${ }^{2}$ & 15 & $19.99 \pm 4.91$ & 15 & $11.02 \pm 3.52$ & 15 & $17.32 \pm 4.48$ & $\begin{array}{l}\mathrm{t}_{\mathrm{a}, \mathrm{b}}=11.865 \mathrm{p}_{\mathrm{a}, \mathrm{b}}=0.000 \\
\mathrm{t}_{\mathrm{a}, \mathrm{c}}=6.941 \quad \mathrm{p}_{\mathrm{a}, \mathrm{c}}=0.000 \\
\mathrm{t}_{\mathrm{b}, \mathrm{c}}=11.151 \mathrm{p}_{\mathrm{b}, \mathrm{c}}=0.000\end{array}$ \\
\hline 6 years old ${ }^{3}$ & 9 & $22.27 \pm 3.68$ & 9 & $12.85 \pm 3.66$ & 9 & $19.87 \pm 3.69$ & $\begin{array}{l}\mathrm{t}_{\mathrm{a}, \mathrm{b}}=14.598 \mathrm{p}_{\mathrm{a}, \mathrm{b}}=0.000 \\
\mathrm{t}_{\mathrm{a}, \mathrm{c}}=11.645 \mathrm{p}_{\mathrm{a}, \mathrm{c}}=0.000 \\
\mathrm{t}_{\mathrm{b}, \mathrm{c}}=11.523 \mathrm{p}_{\mathrm{b}, \mathrm{c}}=0.000\end{array}$ \\
\hline Ind T-test & \multicolumn{2}{|c|}{$\begin{array}{l}\mathrm{t}_{1,2}=1.025 \mathrm{p}_{1,2}=0.314 \\
\mathrm{t}_{1,3}=-0.533 \mathrm{p}_{1,3}=0.599 \\
\mathrm{t}_{2,3}=-1.202 \mathrm{p}_{2,3}=0.242\end{array}$} & \multicolumn{2}{|c|}{$\begin{array}{l}\mathrm{t}_{1,2}=2.924 \mathrm{p}_{1,2}=0.006 \\
\mathrm{t}_{1,3}=1.078 \mathrm{p}_{1,3}=0.291 \\
\mathrm{t}_{2,3}=-1.212 \mathrm{p}_{2,3}=0.238\end{array}$} & \multicolumn{2}{|c|}{$\begin{array}{l}\mathrm{t}_{1,2}=0.960 \mathrm{p}_{1,2}=0.345 \\
\mathrm{t}_{1,3}=-0.964 \mathrm{p}_{1,3}=0.344 \\
\mathrm{t}_{2,3}=-1.433 \mathrm{p}_{2,3}=0.166\end{array}$} & \\
\hline
\end{tabular}


As could be seen from the table, the height of the figures drawn, at home and after the treatment, does not significantly differ in the age groups. There could only be observed that in the 5-year-old children bracket, before and after treatment, the size of the figures is relatively smaller as compared to the rest, with no statistically significant difference amongst the age groups $(\mathrm{p}<0.05)$.

Following the conclusion of the dental treatment, the tendency for the increase of the height of the drawings is kept in all age groups, which is an indicator for the calmness of the children.

Image 1. Drawn Persons, as per Excavation with Brix 3000 - at home $(22 \mathrm{~cm})$, before treatment $(8.2 \mathrm{~cm}$.), after treatment $(17.5 \mathrm{~cm})$

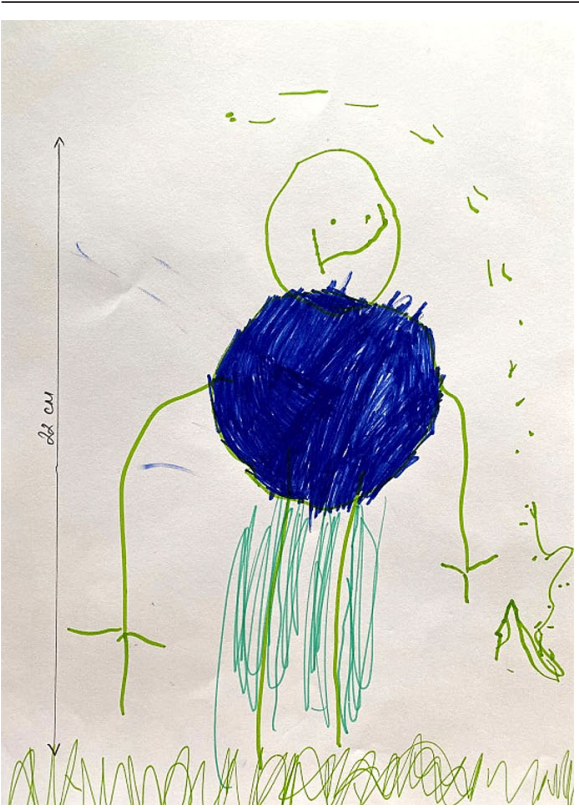

At Home

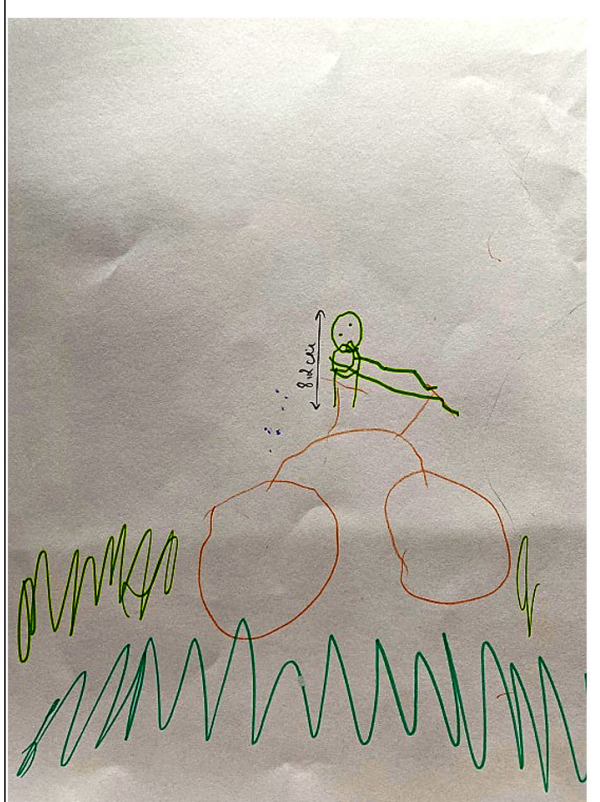

Before Treatment

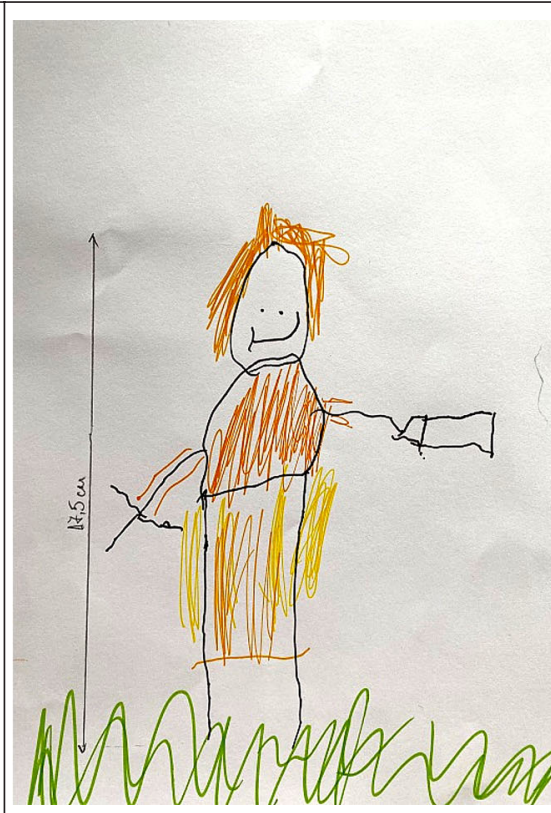

After Treament

Table 3 represents a comparative analysis of the fear of dental treatment via the projective test 'Draw-a-Person' using a conventional and enzyme-based excavation with Brix 3000.

Table 3. Comparative Analysis of the Fear using Bur Excavation and with Brix 3000 - at home, before and after treatment

\begin{tabular}{|c|c|c|c|c|c|}
\hline \multirow{3}{*}{ Figure Height } & \multicolumn{4}{|c|}{ Excavation } & \multirow{3}{*}{ Ind T-test } \\
\hline & \multicolumn{2}{|r|}{ Bur } & \multicolumn{2}{|c|}{ Brix 3000} & \\
\hline & $\mathrm{N}$ & Mean \pm SD & $\mathrm{N}$ & Mean \pm SD & \\
\hline At Home & 30 & $22.33 \pm 2.50$ & 42 & $21.12 \pm 4.10$ & $\mathrm{t}=1.426 \mathrm{p}=0.158$ \\
\hline Before Treatment & 30 & $10.94 \pm 2.48$ & 42 & $12.77 \pm 3.44$ & $\mathrm{t}=-2.490 \mathrm{p}=0.015$ \\
\hline After Treatment & 30 & $15.83 \pm 2.20$ & 42 & $18.41 \pm 3.78$ & $\mathrm{t}=-3.341 \mathrm{p}=0.001$ \\
\hline
\end{tabular}

Immediately before the dental treatment, it could be observed that there is a two-fold decrease in the size of the figure in both groups as compared to the figure drawn at home, which corroborates a heightened fear feeling. Following the conclusion of the treatment, in both groups, an increase in the height of the drawn figure could be observed, and it is worthwhile noting that the height of the figures, drawn by children, where the carious lesions are excavated with Brix 3000, are more similar to those drawn at home than children treated using the conventional method.

\section{DISCUSSION}

According to Sharma and Tyagi, the correct assessment of behavior in children assists the dental doctor in planning the visits in the most effective and efficient possible way [9].

A behavioral assessment was carried out with regards to the examined children as per the Frankl scale, with fear being assessed with the projective test 'Draw-aPerson' in a Brix 3000 enzyme excavation.

The analysis of the drawn figures at home and prior to the treatment under the 'Draw-a-Person' test demonstrated an increase of fear and anxiety, regardless of age 
and sex of the children. Following the conclusion of the excavation with Brix 3000, a decrease in fear and anxiety could be observed. The figures of the drawings made by children are significantly higher in comparison to those drawn before treatment. This is an indicator of the children's calmness and lowers the levels of their anxiety. The projective test 'Draw-a-Person' justifies the acceptance of enzyme-based excavation with Brix 3000 by children experiencing fear from dental treatment.

A significant amount of research could be identified in the literature when it comes to fear and anxiety assessment of children with regards to dental treatment, conducted via various tests. Kilinc et al. examine 90 children aged between 4 and 6 . The measure the fear of examined children based on 4 different scales - by pulse rate, picture scale for fear assessment (Facial Image Scale), Frankl's scale and image test for self-assessing anxiety as per Venham. Children's anxiety is measured before and after treatment. The results corroborate that there is no statistically significant difference in using the 4 scales. According to each of them, children experience fear and anxiety before treatment. Kilinc et al. came to the conclusion that it is difficult to measure the level of dental anxiety as it is a subjective factor that varies amongst the separate groups [10]. Abreu et al. assess the dental fear of children by comparing three different methods of excavation - conventional, atraumatic and ultra-conventional with manual excavators only. The fear assessment is conducted before and after treatment via the Facial Image Scale. The results are the following: the fear of dental treatment is highest immediately before the initiation of the procedure when it comes to the three excavation methods. After the treatment, fear levels decrease the most in relation to the atraumatic method of excavation. The ATR method is preferred by children [11]. These results match our results with regards to Brix 3000.
In Bulgaria, Rashkova et al. examined the attitude of children between 3 and 9 years of age towards chemiomechanical excavation with Carisolv, which is another method of sparing excavation. The authors come to the conclusion that children with a high or low negative attitude as per Frankl generously accept the chemio-mechanical excavation. These results match the ones achieved by us [12].

Another research assesses anxiety and fear of dental treatment with Er-YAG laser-assisted treatment of tooth caries in children with the projective test 'Draw-a-Person'. Their results also corroborate our conclusion [13].

Dental anxiety in the literature is described as a state of anxiety since it appears after the dental treatment and is connected with negative expectations, which are oftentimes related to earlier traumatic experiences, negative family attitudes, fear of pain, unsuccessful or painful previous treatment [14]. In this context, the enzyme-based excavation with Brix 3000 could successfully be implemented in the course of treatment of children with strong or weak negative behavior as per Frankl towards dental treatment.

\section{CONCLUSIONS:}

1. For children aged 4-to-6 there is a determination of heightened fear when it comes to an upcoming treatment and rapid calmness following sparing excavation with Brix 3000;

2 . There are no differences in the fear levels in children aged 4 to 6 , as per their age;

3. Brix 3000 could be successfully implemented with children with a strong or weak negative attitudes as per Frankl;

4. The sparing enzyme-based excavation lowers fear levels in relation to dental treatment with children aged 4 to 6 in comparison to the conventional bur treatment.

\section{REFERENCES:}

1. Kritsidima M, Newton $\mathrm{T}$, Asimakopoulou. The effects of lavender scent on dental patient anxiety leverls: a cluster randomized-controlled trial. Community Dent Oral Epidemiol. 2010 Feb;38(1):83-7. [PubMed]

2. $\mathrm{Ku}^{\circ} \mathrm{cu} \mathrm{OO}$, Akyuz S. Children's preferences concerning the physical appearance of the dental injectors. $J$ Dent Child (Chic). 2006 MayAug;73(2):116-21. [PubMed]

3. Ramos-Jorge ML, Marques LS, Pavia SM, Serra-Negra JM, Pordeus IA. Predictive factors for child behavior on the dental environment. Eur Arch Peadiatr Dent. 2006 Dec;7(4):253-7. [PubMed]

4. Dahlander A, Soares F,
Grindefjord M, Dahllöf G. Factors Associated with Dental Fear and Anxiety in Children Aged 7 to 9 Years. Dent $J$ (Basel). 2019 Jul 1;7(3):68. [PubMed] 5. American Academy of Pediatric Dentistry. Behaviour Guidance for the Pediatric Dental Patient. The Reference Manual of Pediatric Dentistry. Chicago III.: American Academy of Pediatric Dentistry; 2020:292-310. [nternet]

6. Sharma A, Kumar D, Anand A, Mittal V, Singh A, Aggarwal N. Factors predicting Behavior Management Problems during Initial Dental Examination in Children Aged 2 to 8 Years. Int J Clin Pediatr Dent. 2017 JanMar;10(1):5-9. [PubMed]

7. Giacaman RA, Munoz-Sandoval
C, Neuhaus KW, Fontana M, Cha ${ }^{3}$ as R. Evidence-based strategies for minimally invasive treatment of carious lesions: Review of the literature. $A d v$ Clin Exp Med. 2018 Jul;27(7):10091016. [PubMed]

8. Tsolova E. [Management of the behavior of children from 3 to 6 years of age in dental environment] [dissertation]. Sofia (Bulgaria): MU-Sofia, 1989. 171p. [in Bulgarian].

9. Sharma A, Tyagi R. Behavior Assessmesnt of Children in Dental Settings: A Retrospective Study. Int J Clin Pediatr Dent. 2011 JanApr;4(1):35-9. [PubMed]

10. Kilinc G, Akay A, Eden E, Sevinc N, Ellidokuz H. Evaluation of children's dental anxiety levels at a 
kindergarden and a dental clinic. Braz Oral Res. 2016 Aug 18;30(1):S180683242016000100701. [PubMed]

11. de Menezes Abreu DM, Leal SC, Mulder J, Frencken JE. Patterns of dental anxiety in children after sequential dental visits. Eur Arch Peadiatr Dent. 2011 Dec;12(6):298-302. [PubMed]
12. Rashkova M, Georgieva M, Alexieva V. [Minimal invasive treatment of dental caries of children, using chemo-mechanical excavation with Carisolv.] Problems of Dental medicine. 2011; 37(1):15-22. [In Bulgarian].

13. Zhegova G, Rashkova M. [Evaluation and behavior's modeling in children at Er:YAG laser-assisted caries treatment.] Problems of Dental medicine. 2013; 39(1):5-11 [In Bulgarian].

14. Bay EJ, Algase DL. Fear and anxiety: a simultaneous concept analysis. Nurs Diagn. 1999 JulSep;10(3):103-11. [PubMed]

Please cite this article as: Lazarova Z, Tankova H, Rashkova M. Fear Assessment with the 'Draw a Person' Test of the Dental Treatment in Sparing Enzyme-Based Excavation of Caries in Children between 4 and 6 Years of Age. J of IMAB. 2021 Oct-Dec;27(4):4043-4047. DOI: https://doi.org/10.5272/jimab.2021274.4043

Received: 19/04/2021; Published online: 18/10/2021

\section{Address for correspondence:}

Zornitsa Branimirova Lazarova

Department of Pediatric Dentistry, Faculty of dental medicine, Medical University - Sofia,

1, Georgi Sofiisky str., Sofia, Bulgaria

E-mail: z.lazarova@fdm.mu-sofia.bg, 